\title{
THE WELD RIVER GROUP: A MAJOR UPPER PRECAMBRIAN DOLOMITE SEQUENCE IN SOUTHERN TASMANIA
}

\author{
by C. R. Calver
}

(with two text-figures and two plates)

CALVER, C.R., 1989 (31:x): The Weld River Group: a major upper Precambrian dolomite sequence in southern Tasmania. Pap. Proc. R. S•c. Tasm. 123: 43-53. https://doi.org/10.26749/rstpp.123.43

ISSN 0080-4703. Geological Survey of Tasmania, Pox 56, Rosny Park, Australia 7018.

The Weld River Group is a folded Precambrian sequence (several kilometres thick and predominantly of dolomite) that crops out in the northern Jubilee region, southern Tasmania. It overlies older predominantly siliciclastic sequences with paraconformity or angular unconformity that does not correspond to any major (cleavage-forming) tectonometamorphic event in the older successions. The group consists of a basal, relatively thin, siliciclastic unit (the Annakananda Formation), locally overlain by an impersistent pebbly mudstone (the Lake Timk Formation), followed by massive, fine-grained dolomite (the Gomorrah Dolomite), then bedded dolomite largely consisting of catagraphic, oolitic grainstone (the Devils Eye Dolomite), and then a second massive dolomite unit (the Styx Dolomite). In faulted contact with these units is a probably younger sequence of massive dolomite intercalated with dolomite-derived mixtite, mudstone and sandstone (the Cotcase Creek Formation). The older Precambrian siliciclastic sequences and the Weld River Group are unconformably overlain by a lithicwacke and conglomerate succession, probably of Middle or Upper Cambrian age. The stratigraphic setting of the group, and some lithologic features, suggest correlation with upper Precambrian dolomitic sequences in northwestern Tasmania (e.g. Black River Dolomite, Success Creek Group) implying that the Penguin Orogeny may be absent or only weakly manifested in the Jubilee region.

Key Words: Precambrian, Tasmania, dolomite, tillite.

\section{INTRODUCTION}

Inaccessibility, thick vegetation and the apparent lack of economic mineral deposits have long discouraged any significant geological interest in the catchments of the upper Weld and upper Styx Rivers. Lewis (1924) provided an exploratory account and a precursory geological map. Spry (1962), in a synthesis of the Precambrian of Tasmania, included the area in a larger region of relatively unmetamorphosed Precambrian rocks, later called the Jubilee Block (Corbett 1970) or the Jubilee region (Turner 1989a). Only recently were large tracts of Precambrian dolomite recorded in the upper Weld valley (Hall 1967). Geological mapping of the Pedder 1:50000 Quadrangle (Turner et al. 1985) first established the essential unity of the dolomite sequence, its structure, internal stratigraphy and relationships with other sequences. A brief outline of this work was given by Calver (1989).

This paper is a more detailed description of the dolomite sequence, incorporating new information from mapping on the Styx Quadrangle. New stratigraphic names are proposed and matters of broader interest are briefly dealt with: e.g. correlation with sequences elsewhere in Tasmania; the nature and timing of major tectonic phases; and the origin of the mixtites and related rocks that occur in younger parts of the succession. Some aspects of this work, in particular dolomite petrography and Pedder Quadrangle geology, will be treated in more detail in Calver et al. (in prep.).

\section{GEOLOGICAL SETTING}

The Weld River Group is the youngest of at least three distinct Precambrian successions that comprise the northern part of the Jubilee region (fig. 1). All the Precambrian rocks are thick, cratonic, shallow-water sedimentary sequences (orthoquartzites, pelites, dolomites) in which regional metamorphism is slight (sub-greenschist facies) to negligible. First-order folds, with wavelengths of a few kilometres, face northwest, plunge steeply northwest and are upright or overturned to the northeast. The folds are thoroughly dismembered by major faults.

The rocks are multiply deformed but the intensity of deformation and metamorphism decreases in a 


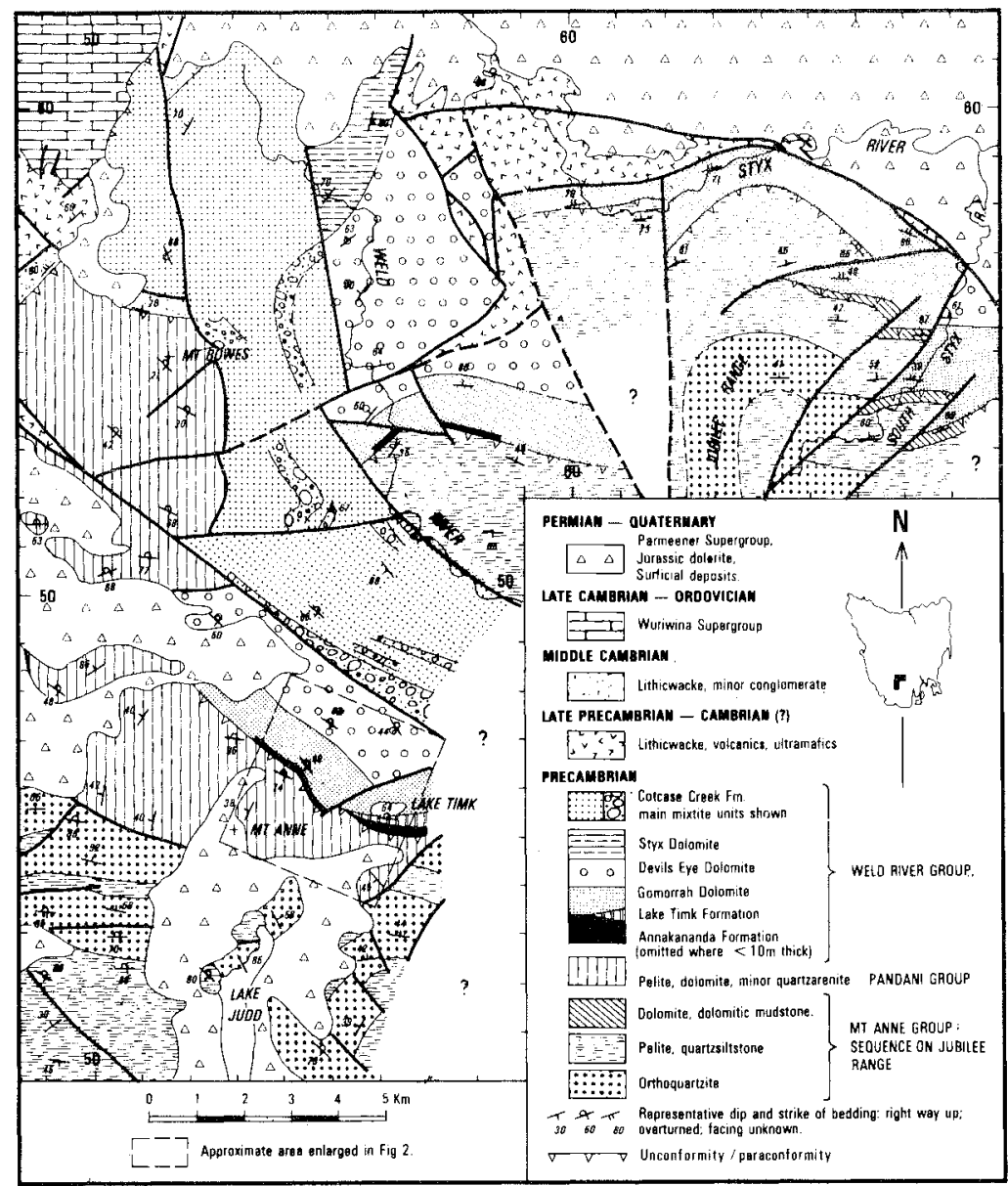

FIG. 1-Geological map of upper Weld Valley and environs. That part of map west of $59 \mathrm{~km}$ E gridline is adapted from Turner et al. (1985).

general northeasterly direction. This is manifested chiefly by a gradual change in pelite character, from fine-grained phyllite south of Mt Anne, through slate around Sandfly Creek (DN500500), to weakly cleaved mudstone around Mt Bowes and east of the Weld River.

All these sequences, including the Weld River Group, are presumed late Precambrian, because of the total absence of fossils other than simple algal remains (stromatolites, catagraphs) and because their rock types and tectonomorphic grade are consistent with known upper Precambrian rocks of the Tyennan and Rocky Cape regions (Turner 1988). They are unconformably overlain to the north by a Middle or Upper Cambrian lithicwackeconglomerate sequence, and faulted against a similar lithicwacke-mafic volcanics sequence of unknown age. All these rocks are unconformably overlain by upper Cambrian to Devonian rocks of the Wurawina Supergroup and by the flat-lying Permo-Carboniferous Lower Parmeener Supergroup. 


\section{STRATIGRAPHY}

\section{Older Precambrian Sequences}

The base of the Weld River Group is regionally transgressive. East of the Weld River it paraconformably overlies an orthoquartzite-quartz siltstone-mudstone sequence (here informally called the "Jubilee Range sequence"), while in a separate area of outcrop north of Mt Anne, it overlies, with angular unconformity, a dolomite and mudstone sequence (the Pandani Group - Calver et $a$., in prep.). The relationship between the Jubilee Range sequence and the Pandani Group is uncertain. The former is lithologically very similar to the Mi Anne Group (Calver et al., in prep.), which crops out extensively south of the Pandani Group and may be older, as it occupies a southerly position in a predominantly north facing structural regime.

A thick (c. $1 \mathrm{~km})$ unit of greenish-grey mudstone monotonously interlaminated with quartz siltstone is generally the topmost unit of the Jubilee Range sequence. Orthoquartzite occurs lower in the sequence and forms the high strike ridges of the Jubilee Range. At the South Styx River, however, the mudstone-quartz siltstone unit grades up into an unusual unit of stromatolitic and oolitic dolomite and dolomitic mudstone, about $100 \mathrm{~m}$ thick, which is then overlain by the Weld River Group. Although showing greater compositional affinity with this group than with the Jubilee Range sequence, the unit is clearly part of the latter as it is gradational with, and to a small extent interbedded with the greenish-grey mudstone-siltstone unit and is overlain by a conglomerate bed correlated with the basal Annakananda Formation of the Weld River Group. The localised distribution of this unit suggests gentle overstep by the Weld River Group over the Jubilee Range sequence, even though at known localities the two sequences show no discernible angular unconformity.

The unconformity on the northeastern ridge of Mt Anne, by contrast, exhibits $20-30^{\circ}$ of angular discordance. The Pandani Group there consists predominantly of dark grey, fine-grained slightly impure dolomite and limy dolomite interbedded with slate and phyllite.

\section{Weld River Group}

The Weld River Group is defined as the sequence (predominantly of dolomite) composed of the formations defined below, occupying most of the catchment of the upper Weld River and extending east into the Styx River valley (fig. 1). Lithologically, it is marked by a great predominance of fine-grained, pale-grey dolomite that appears relatively pure except for local secondary silicification. Total apparent thickness of the Group is of the order of $5 \mathrm{~km}$, but known faulting, and more especially the undoubted presence of undetected faulting in this generally poorly exposed area, make estimates of stratigraphic thickness fraught with uncertainty. The sequence is thought to be wholly Late Precambrian in age (for reasons outlined above).

The Weld River Group is regionally folded but the thick dolomite units have bchaved competently and appear unstrained at the scale of outcrop or thin-section. The volumetrically minor clastic units are, by contrast, usually cleaved and in a few places display outcrop-scale folding.

Difficulty of access, inadequate exposure and the great thicknesses of the constituent formations have precluded measurement of type sections: definition is by type area, and conformity and continuity of the sequence are inferred from constancy of bedding attitude and facing in type areas.

Karst topography is developed over much of the area occupied by the Weld River Group. Scattered surficial boulders of crystalline and chalcedonic quartz, often with much vuggy porosity, are very common, particularly in the Styx River catchment. These may be remnants of an ancient (Tertiary?) silcrete.

\section{Annakananda Formation}

The Annakananda Formation is defined as the formation of conglomerate and lithic sandstone, approximately $30 \mathrm{~m}$ thick, which overlies the Pandani Group with angular unconformity on the northeastern ridge of Mt Anne (DN543463) and is conformably overlain by the Gomorrah Dolomite. The formation is named after the major cave system that leads from the bottom of the large sinkhole at this locality. These karst features are developed in the basal part of the Gomorrah Dolomite. The surface of unconformity and adjacent bedding over a wide area are overturned and dip steeply southwest (figs 1,2). At the type locality, all but the lowermost $1.5 \mathrm{~m}$ of the unit are well exposed in the precipitous southern wall of the sinkhole. Here the Annakananda Formation consists of (at the base) several metres of thinbedded, yellowish brown, dolomitic lithic sandstone (in places cross-bedded and ripplemarked), followed by roughly $10 \mathrm{~m}$ of massive 


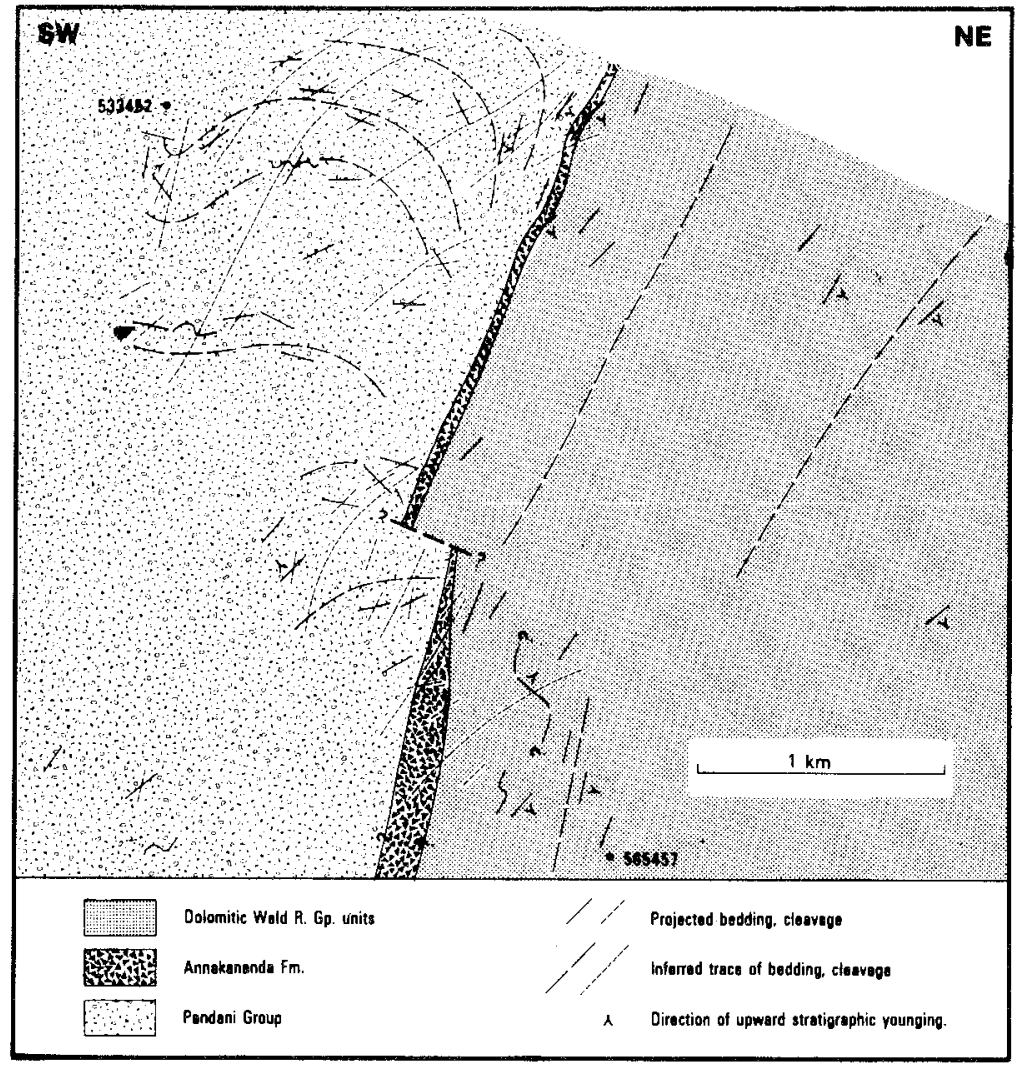

Fig. 2 - Structural profile, northeastern ridge of Mt Anne. Projection plane: view to $294^{\circ}$, elevation $40^{\circ}$.

conglomerate, then roughly $10 \mathrm{~m}$ of thick-bedded, fine-grained, brown dolomitic sandstone which grades up conformably into the massive grey dolomite of the succeeding Gomorrah Dolomite. The conglomerate is predominantly reddish in colour, closed-framework, and of pebble to cobble grade. It is mostly or entirely composed of clasts derived from the underlying Pandani Group: dolomite, dolomitic mudstone, orthoquartzite, phyllite and chert.

Along strike to east and west of the type locality, conglomerate is the predominant rock type; the formation thickens to approximately $100 \mathrm{~m}$ south of Lake Timk. In a separate area of outcrop east of the Weld River and north of the Jubilee Range, the Annakananda Formation correlate rests paraconformably upon the Jubilee Range sequence. In the Weld River (DN563533), the formation consists of a basal $300 \mathrm{~mm}$ thick bed of pebble- conglomerate, with clasts derived from underlying rock types (quartz siltstone and mudstone), overlain by about $10 \mathrm{~m}$ of red mudstone, with minor thin, planar laminae of lithic sandstone. Identical red mudstone separates the Jubilee Range sequence from a correlate of the Gomorrah Dolomite on the Styx River at DN603580. In the South Styx River area, where a dolomitic unit locally occurs at the top of the Jubilee Range sequence (see above), the Annakananda Formation correlate consists of a few metres of sandy dolomitic conglomerate and breccia.

\section{Lake Timk Formation}

The Lake Timk Formation is defined as the unit of pebbly dolomitic mudstone and siltstone that crops out immediately south of Lake Timk, in a position stratigraphically between, and structurally 
conformable with the Annakananda Formation and the Gomorrah Dolomite. The formation (up to $300 \mathrm{~m}$ thick) appears to thin westward and disappears west of Lake Timk, suggesting stratigraphic impersistence, but, as neither base nor top is exposed, fault emplacement cannot be ruled out. Bedding is overturned and dips south. The formation consists of black to grey-green mudstone, with thin planar laminae of lightercoloured quartz-rich siltstone and sparse floating granules and pebbles of dolomite and quartzite in places.

\section{Gomorrah Dolomite}

The Gomorrah Dolomite is defined as the unit of massive, fine-grained, pale-grey dolomite, about $800 \mathrm{~m}$ thick, conformably overlying the Annakananda Formation in the sinkhole exposure described above and overlain conformably by the Devils Eye Dolomite at around DN550468 on the northeastern ridge of Mt Anne. The top was not observed but may be defined as the base of the first occurrence of predominantly bedded dolomite that is characteristic of the Devils Eye Dolomite. The formation is named after the large eastern spur (DN555465) of Mt Anne's northeastern ridge.

Most outcrops are massive and uniform, typically with a network of etched, fine, random fractures or joints and, in places, veins of dolomite or quartz. In some outcrops, primary lamination is preserved as colour-banding or as slight textural variations, manifested as a relief-pattern on weathered outcrop surfaces. Thin sections show an anhedral, recrystallised fabric with lamination, where present, defined by variations in grainsize $(0.02-0.2 \mathrm{~mm})$. Indistinct, slightly opaque clots which are present may be ghosts of original peloids. Rare beds of grainstone (see below) are present. A few outcrops contain up to $30 \%$ wellrounded quartz sand grains. There are rare siliciclastic intervals, notably an impersistent unit of interbedded mudstone, lithic sandstone and minor chert locally cropping out just west of Lake Timk.

A lithostratigraphic correlate of the Gomorrah Dolomite occurs in the Weld Valley and extends east, offset by several faults, to the South Styx River.

\section{Devils Eye Dolomite}

The Devils Eye Dolomite is defined as the unit of predominantly bedded dolomite, conformably overlying the Gomorrah Dolomite (as described above) at DN550468 on the northeastern ridge of Mt Anne. This section is terminated by a major fault $1300 \mathrm{~m}$ above the base of the Devils Eye Dolomite, so a composite type area is necessary and the top of the formation is defined where its lithological correlate in the Weld River area is overlain by the Styx Dolomite at DN554578. Here also the formation is faulted; the thickest apparently unfaulted section is about $2.5 \mathrm{~km}$ thick. However, poor exposure and the possibility of undetected faulting render this uncertain as an estimate of stratigraphic thickness. The name of the formation is derived from a large cave at DN556472.

Like the underlying Gomorrah Dolomite, this formation is composed almost entirely of clean, pale-grey dolomite but is distinguished by the presence of numerous beds in which arenaceous or rudaceous grainstone textures are preserved. In some outcrops, grainstone is pervasive, but usually there is considerable interlayered fine-grained, uniform dolomite. Bedding in weathered outcrops is usually enhanced by selective partial silicification of the grainstone layers and is thus readily discernible in most place, unlike the situation in the predominantly massive dolomite of the rest of the Weld River Group.

The grainstone beds are usually gently lenticular and are frequently cross-bedded, with sets $0.05-0.1 \mathrm{~m}$, rarely $0.2 \mathrm{~m}$ in thickness. Herringbone cross-bedding is common. Locally developed at the bases of some beds, and filling shallow scours, are thin lenses of flat-pebble breccia.

In thin sections, the primary constituents of the grainstones are generally well-preserved and can be identified as catagraphs, ooids, peloids and intraclasts (pl. 1). Catagraphs (spheroidal to irregular grains with micritic rims, possibly of microbial origin: Hofmann 1987) are the most abundant component volumetrically (pl. 1A). Ooids are all concentrically layered, lack radial structure and are often compound (pl. 1B). Pure oolite rock is rare. Flat-pebble breccias often exhibit a geopetal fabric (shelter porosity) (pl. 1C).

No siliciclastic rocks are known from this formation. A dolomite pebble-cobble conglomerate, almost wholly of intrabasinal provenance but for rare orthoquartzite clasts, crops out on the faultline scarp (DN560480) that terminates the northeastern ridge section.

\section{Styx Dolomite}

The Styx Dolomite is defined as the unit of massive, pale-grey, fine-grained dolomite that 

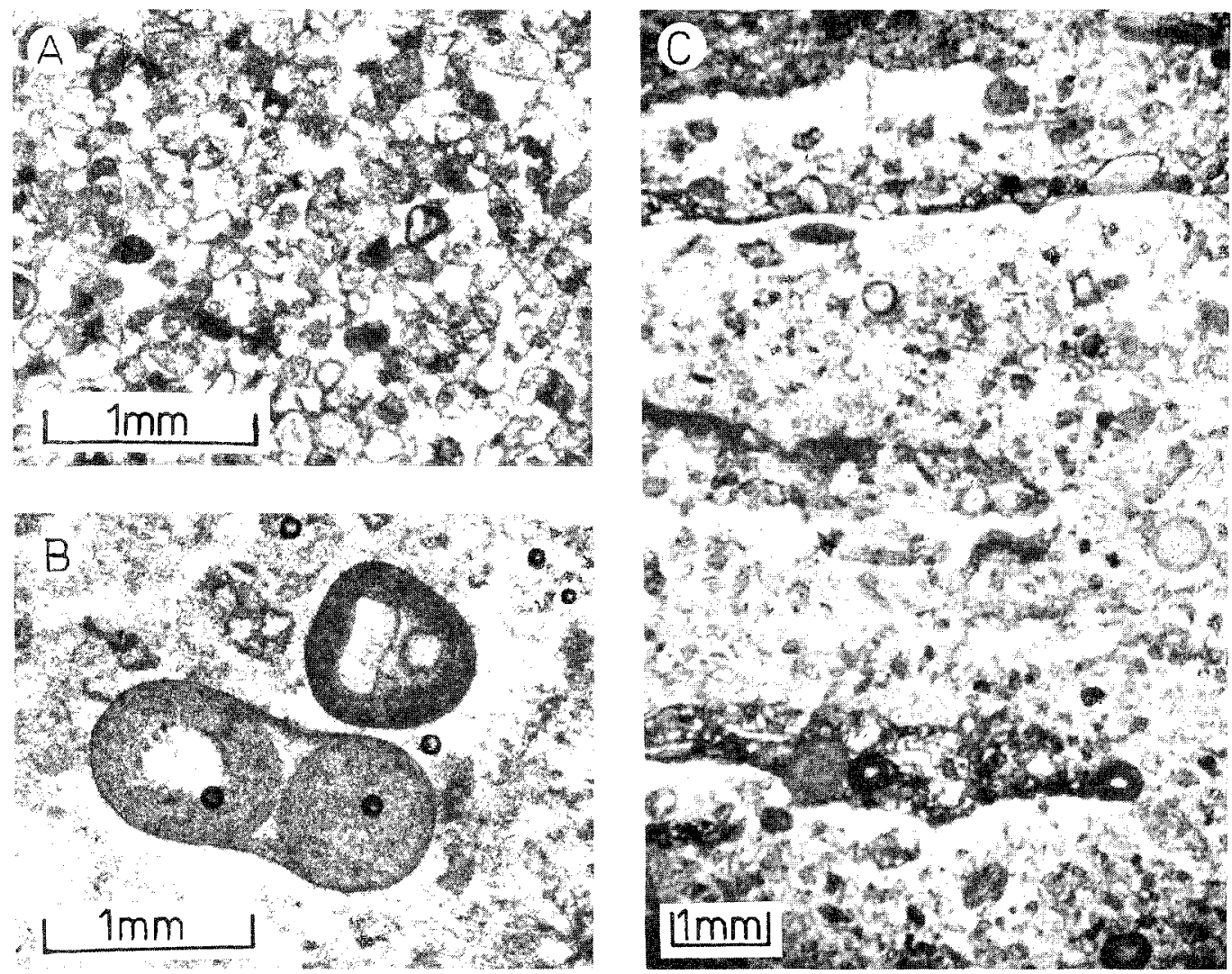

PLATE I

Photomicrographs, with plane-polarised light, of grainstone types from the Devils Eye Dolomite: (A) catagraphic grainstone, $(B)$ oolitic grainstone, (C) intraclastic grainstone. Light-coloured areas immediately beneath large platy intraclasts in $(C)$ are cement-filled voids (shelter porosity).

overlies, probably conformably, the Devils Eye Dolomite in the Weld River at DN554578; the base is taken as the top of the last grainstone bed. The formation is well-exposed upstream as far as DN548581, this section representing an apparent thickness of about $500 \mathrm{~m}$, but is poorly known elsewhere; the top of the unit is not exposed. To the west, the Styx Dolomite is faulted against the Cotcase Creek Formation; it may be partly equivalent to this formation but appears to lack the characteristic mixtite units.

The predominant rock type is that typical of massive dolomite elsewhere in the Weld River Group (Gomorrah Dolomite, Cotcase Creek Formation). Most outcrops in the lower $300 \mathrm{~m}$ of section in the Weld River contain several per cent rounded quartz sand grains, which tend to be scattered through the rock without being concentrated into beds or laminae; oolitic coatings were observed on some quartz grains. Near the top of the river section there are two small outcrops of red mudstone with thin planar sandstone laminae.

\section{Cotcase Creek Formation}

The Cotcase Creek Formation is defined as the unit, predominantly of massive, fine-grained, pale-grey dolomite, with intervals of mixtite, sandstone, mudstone and chert, that occupies the western half of the catchment of the upper Weld River (fig. 1). It is named after a western tributary of the Weld.

The formation is poorly known due to difficulty of access, poor outcrop and the paucity of facing evidence; no top or base to the sequence is known. 
It is faulted against other units of the Weld River Group. Although there is no proven stratigraphic continuity with the other units, this formation is included in the Weld River Group on the basis of proximity and similar gross character to the previously described formations. Since the other formations constitute a well-established sequence overlying dissimilar, older Precambrian rocks, the Cotcase Creek Formation is taken to be younger.

Sparse facing evidence suggests the whole outcrop belt may be the steeply west-dipping limb of a fault-modified, first-order, northwest-plunging anticline, with a northern limb represented by the north-dipping rocks east of the Weld River (fig. 1). Rare reversals of facing imply tight folding and greater structural complexity, but no closures were mapped in the field. A conservative thickness estimate of, say, $2 \mathrm{~km}$ necessitates some structural repetition to account for the full width $(3-4 \mathrm{~km})$ of the outcrop belt.

Dolomite in the Cotcase Creek Formation is lithologically identical to the other largely massive, fine-grained units (Gomorrah and Styx Formations). There are rare, isolated grainstone beds similar to those of the Devils Eye Dolomite.

Several mixtite units have been mapped, ranging from a few metres to perhaps $400 \mathrm{~m}$ thick. In some instances they appear to be laterally impersistent, although poor outcrop and the strong possibility of undetected faulting render this an uncertain observation. Typically the unit is a wholly massive rock composed of 5-30\% angular to sub-rounded clasts, pebble to cobble size (rarely, to boulder size), in a black, carbonaceous, dolomitic sandy mudstone matrix (pl. 2A). In places there is a weak cleavage and weak tectonic alignment of clasts. The clasts are predominantly white to pale-grey dolomite identical to the enclosing sequence, with minor mudstone, orthoquartzite, quartz siltstone, chert and a single altered basaltic fragment. Contacts of mixtite units with the enclosing dolomite sequence are generally abrupt or marked by an intervening unit of laminated black mudstone, black quartzwacke or dolomite conglomerate. Dolomite clasts in the conglomerates and mixtites are all recognisable Weld River Group types, except for an unusual variety of oolite consisting of very small $(0.07-0.25 \mathrm{~mm})$ radialfibrous ooids.

There is some variation (within and between mixtite units) in composition, maximum clast size and clast-matrix proportion. For example, a unit about $200 \mathrm{~m}$ thick, just south of the Weld River (DN562513), has a few metres of black dolomitic quartzwacke at the base, followed by boulder
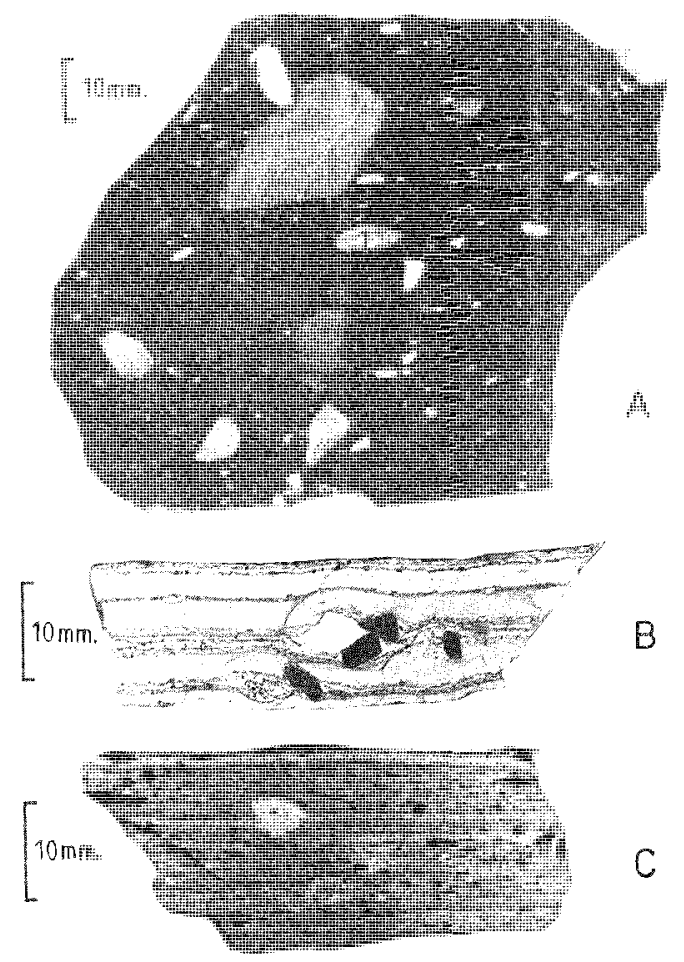

PLATE 2

(A) Polished slab of mixtite and $(B, C)$ etched slabs of pebbly laminated dolomite, all from Cotcase Creek Formation. Note possible till clast in $(B)$. Orientation uncertain.

mixtite with abundant (30\%) clasts, then sparse (5\%) mixtite making up the bulk of the unit, with more clast-rich rock reappearing near the top contact. In some other localities, no clasts larger than granules are present.

At a southern locality (DN570487), mixtite is interlayered on a scale of metres to tens of metres with laminated pebbly dolosiltite. The dolosiltite is thinly planar-laminated, pale grey in colour and rich in detrital quartz sand and silt; it contains sparse floating granules, pebbles and rare cobbles of dolomite (pl. 2B,C). The laminae are deformed by differential compaction about these clasts. Some granules and small pebbles are clumped together in loose aggregates, a structure that resembles that of some till clasts (pl. 2B).

Also intercalated with the Cotcase Creek Formation are minor units of mudstone and siltstone, rare chert and rare quartz sandstone. In the 
northwestern part of the outcrop area, in probably the younger parts of the formation, labile sandstone, quartz sandstone and chert become more prevalent (Turner et al. 1985).

\section{Lithicwacke Sequences}

\section{(? Late Precambrian-Cambrian)}

Juxtaposed with the Weld River Group in several northern localities are two, more or less distinct lithicwacke-dominated successions. Contacts between these two sequences and with the Weld River Group are faults or probable faults.

One sequence is clearly younger than the Weld River Group as it commonly contains detritus that appears to be derived from the latter. It overlies the Pandani Group with angular unconformity north and northwest of Mt Bowes; conglomerate at or near the base contains abundant, disoriented, cleaved clasts of Pandani Group derivation, as well as Weld River Group-derived clasts. Therefore, the sequence must unconformably overlie the Weld River Group as well. Quilty (1971) recorded a Middle or Upper Cambrian fauna at a nearby locality from rocks probably belonging to this sequence (Turner et al. 1985), and it is probably the same one which crops out extensively in the eastern foothills of Mt Mueller (not shown on fig. 1 but see Turner et al. 1985). The rocks are generally well-bedded and the lithicwackes are quartz-rich, with abundant metamorphic rock fragments, some dolomite rock fragments and very rare volcanic rock fragments.

The other lithicwacke-dominated succession crops out extensively in the upper Styx catchment (fig. 1). It contains pillow basalts and chert, and is associated with serpentinised ultramafic bodies. Stratification is massive or obscure, and lithicwackes contain common basaltic rock fragments, biotite and plagioclase, as well as metamorphic rock fragments. Metamorphic rock fragments in both sequences are schistose, suggesting derivation from the higher-grade Tyennan region to the west rather than from the Jubilee region. This latter, unfossiliferous lithicwacke sequence is of uncertain age but is thought to be also younger than the Weld River Group, due to its position in this regionally northfacing pile and its affinities being clearly with the middle Cambrian sequence rather than with the cratonic shallow-water Precambrian sequences.

The Middle or Upper Cambrian lithicwacke succession is a correlate of the Island Road
Formation, while the other, volcanic-associated sequence appears to be a correlate of the Ragged Basin Complex (Turner 1989b).

\section{DEPOSITIONAL ENVIRONMENTS}

The older Precambrian sequences evidently experienced gentle tilting and erosion before Weld River Group sedimentation began. Proximal conglomerates were laid down on tilted Pandani Group basement while a thinner, finer-grained, more distal facies was deposited on the relatively undisturbed Jubilee Range sequence. Then followed a very great thickness of almost entirely carbonate sedimentation. If superposition of the Cotcase Creek Formation on the other units is assumed, then a total thickness of the order of $5 \mathrm{~km}$ for the Weld River Group is obtained. This estimate is necessarily highly imprecise because of the structural uncertainties previously mentioned.

As a rule, carbonate sedimentation requires a warm, shallow marine environment free of terrigenous influx (Wilson 1975). The depositional environments of the massive, fine-grained dolomites (Gomorrah, Styx and Cotcase Creek Formations) remain otherwise enigmatic. Grainstones in the Devils Eye Dolomite and at rare horizons elsewhere indicate a shallow and constantly agitated tidal shelf environment.

The mixtites of the Cotcase Creek Formation may be either tillites or mudflow deposits. Discrimination between these two modes of origin, although of great palaeoclimatological importance, is difficult (Schermerhorn 1974); no convincing proof of either mechanism has yet been found in the Cotcase Creek Formation. A debris-flow origin is favoured by the almost wholly intrabasinal provenance of the clasts, and the apparent lateral impersistence of some mixtite units. Observed variations in maximum clast size may be due to proximal settling of larger clasts during transport. No facetting or striation of clasts was observed but these would be difficult to identify, as matrix and clasts are equally indurated. The abruptness of the contacts and the general lack of a glacial imprint on the enclosing sequence also militate against a glacial origin. However, the pebbly laminated mudstone comprising the Lake Timk Formation and the rare pebbly laminated dolosiltite in the Cotcase Creek Formation are suggestive of a local glaciomarine imprint. Significant in this regard is the occurrence, at widespread localities elsewhere in Tasmania, of mixtites of possibly similar age (see below). 
The juxtaposition of rocks of possible glacial origin with warm-water carbonates is a paradox that has been widely documented in late Precambrian sequences (e.g. Williams 1975). Although scarcely credible in uniformitarian terms, there is strong evidence to suggest that more or less abrupt changes from one climatic extreme to the other did occur at this time (Williams 1975).

\section{RELATIVE AGE OF DEFORMATION}

Two regionally significant phases of deformation have affected the Pandani Group and adjacent parts of the Weld River Group. The first $\left(\mathrm{D}_{1}\right)$ produced a first-order anticline in the Mt Anne-Mt Bowes area, plunging northwest and overturned to the northeast, with a pervasive axial planar slaty cleavage developed in pelitic rock types. The hinge zone lies within the Pandani Group (fig. 2), and the overturned part of the Weld River Group (that section exposed along the northeast ridge of $\mathrm{Mt}$ Anne) represents part of the overturned northeastern limb of this structure. $S$ cleavage is developed in siliciclastic units within the Weld River Group and is concordant across the unconformity (fig. 2). The second phase ( $D_{2}$ ), coaxial with the first, produced a crenulation widespread in the Pandani Group but only locally developed in the Weld River Group.

East of the Weld River, the Precambrian rocks are only weakly deformed, with a weak beddingparallel slaty cleavage $\left(\mathrm{S}_{1}\right.$ ?) affecting mudstones in both the Jubilee Range sequence and the Annakananda Formation correlate. There is also a locally developed weak crenulation associated with upright, northwest-trending minor folds in the Jubilee Range sequence.

Outcrop and thin-section examination of Annakananda Formation conglomerates in both the Mt Anne and Weld River localities reveal no predepositional cleavage in the constituent clasts, which in both areas appear to be derived from the underlying rocks. By contrast, the Middle or Upper Cambrian conglomerate north of $\mathrm{Mt}$ Bowes contains Pandani Group-derived clasts with a slaty cleavage that clearly pre-dates deposition of the conglomerate.

Thus, the earliest known and most significant deformation $\left(D_{1}\right)$ affecting the Precambrian rocks of the northern Jubilee region is post-Weld River Group and pre-Upper Cambrian in age.

\section{CORRELATION}

The broad stratigraphic setting of the Weld River Group is similar to that of pre-middle Cambrian sequences widespread in western Tasmania, in which a dolomitic shallow-water sedimentary unit unconformably overlies predominanty siliciclastic Precambrian rocks and is succeeded by volcanosedimentary sequences suggestive of deepening and basin instability. On this basis, the Success Creek Group (Brown 1986), the Ahrberg Group (Turner 1988), the Black River Dolomite-Forest Conglomerate sequence (Spry 1964, Brown 1989), possibly the Trowutta Breccia and underlying rocks (Jago 1981), and the Jane Dolomite (Spry \& Zimmerman 1959) may be lithostratigraphic correlates of the Weld River Group. All these sequences have been correlated at one time or another (e.g. Spry 1962, Williams 1976). Most contain mixtites or sedimentary breccias (Griffin \& Preiss 1976, Brown 1986, 1989, Jago 1981, Spry \& Zimmerman 1959).

However, correlation of the Weld River Group with these sequences is inconsistent with the relative age of the Penguin Orogeny in the northwestern Tasmania sequences. The Black River Dolomite-Forest Conglomerate sequence and the Success Creek Group (but possibly not the Ahrberg Group: Turner 1988) unconformably overlie rocks deformed in the Penguin Orogeny (Williams 1976) but, as shown above, the unconformity at the base of the Weld River Group does not correspond to any comparable folding or cleavage-forming event in the underlying rocks.

Whether the Penguin Orogeny was felt as a significant event outside northwestern Tasmania is currently a matter of contention. Turner (1988, 1989a) regards the Penguin Orogeny as a fundamental benchmark event throughout the Tasmanian Precambrian. On the other hand, one interpretation of preliminary radiometric dating of metamorphic events (Adams et al. 1985) and some geological evidence (Brown 1989: 48) suggest that the structural history in northwestern Tasmania was different from the rest of Tasmania in pre-middle Cambrian times.

Under this latter scenario, correlation of the Weld River Group with the post-Penguin Orogeny sequences of northwest Tasmania is consistent with the known timing of tectonic phases. A diminished Penguin Orogeny perhaps caused the hiatus and local tilting prior to Weld River Group deposition. The main deformation in the northern Jubilee region Precambrian rocks ( $D_{1}$ of this paper) may then be equivalent to the significant early Cambrian 
event determined from metamorphic radiometric dates from the Tyennan region (Raheim \& Compston 1977, Adams et al. 1985).

\section{DISCUSSION}

The Weld River Group constitutes a significant late Precambrian dolomite sequence that was, until recently, virtually unknown. The thickness of the Group indicates a substantially more complete succession than any of the proposed correlates in western and northwestern Tasmania. Work is continuing on mapping, stratigraphy, palaeoenvironments, and diagenesis of these rocks. Conclusive identification of glacigene rocks, with important stratigraphic and palaeoenvironmental implications, remains to be achieved.

If the correlation and relationships with isotopically dated metamorphic events postulated above are correct, then the age of the Weld River Group is bracketed below by the Penguin Orogeny (c. $725 \mathrm{~m} . \mathrm{y}$ ) and above by the early Cambrian (c. 540-610 m.y.) event of Adams et al. (1985) and Raheim \& Compston (1977). This age range invites comparison with the Late Adelaidean (750-570 m.y., Dunn et al. 1971) sequences of South Australia, which include significant tillites and shallow-water carbonates (ibid.).

It must be emphasised, however, that the suggested correlation of the Weld River Group with the Success Creek Group and its correlates in northwestern Tasmania remains tentative, being based on broad lithostratigraphic criteria and lacking any direct chronostratigraphic or biostratigraphic basis. In this context, selective isotopic dating within the Jubilee region would clarify relationships with other Tasmanian Precambrian sequences, where some measure of chronostratigraphic control already exists.

\section{ACKNOWLEDGEMENTS}

I thank N.J. Turner and E. Williams for useful discussions. This paper is published with the permission of the Director of Mines.

\section{REFERENCES}

Adams, C.J., Black, L.P., Corbett, K.D. \& Green, G.R., 1985: Reconnaissance isotopic studies bearing on the tectonothermal history of Early Palaeozoic and Late Proterozoic sequences in western Tasmania. Aust. J. Earth Sci. 32: 7-36.

Brown, A.V., 1986: Geology of the Dundas-Mt Lindsay-Mt Youngback region. Bull. Geol. Surv. Tasm. 62.

Brown, A.V., 1989. Eo-Cambrian-Cambrian. In Burrett, C.F. \& Martin, E. (Eds): GEOLOGY AND MINERAL RESOURCES OF TASMANIA. Geol. Soc. Aust. Spec. Publ. 15: 47-83.

Calver, C.R., 1989. The Jubilee Region. In Burrett, C.F. \& Martin, E. (Eds): GEOLOGY AND MINERAL RESOURCES OF TASMANIA. Geol. Soc. Aust. Spec. Publ. 15: 53-54.

Calver, C.R., McClenaghan, M.P., Turner, N.J., Brown, A.V., McClenaghan, J. \& Boulter, C.A., in prep.: Pedder. Geol. Atlas 1:50 000 ser. Explan. Rep. Sheet $8112 \mathrm{~S}$. Tasm. Dep. Mines.

CorbetT, K.D., 1970: Sedimentology of an Upper Cambrian flysch-paralic sequence (Denison Group) on the Denison Range, southwest Tasmania. Unpubl. Ph.D. thesis, Univ. Tasm.

Dunn, P.R., Thomson, B.P. \& Rankama, K., 1971: Late Precambrian glaciation as a stratigraphic boundary. Nature 231: 498-502.

Griffin, B.J. \& Preiss, W.V., 1976: The significance and provenance of stromatolitic clasts in a probable Late Precambrian diamictite in northwestern Tasmania. Pap. Proc. R. Soc. Tasm. 110: 111-127.

HALL, W.D.M., 1967: Report of geological investigations, S.W. Tasmania, E.L.13/65. Unpubl. rep. Broken Hill Pty Co. Ltd.

Hofmann, H.J., 1987: Paleoscene no.7: Precambrian biostratigraphy. Geosci. Can. 14: 135-154.

JAGO, J.B., 1981: Possible Late Precambrian (Adelaidean) tillites of Tasmania. In Hambrey, M.J. \& Harland, W.B. (Eds): EARTH'S PRE-PLEISTOCENE GLACIAL RECORD. Int. Geol. Correlation Programme, Project 38: Pre-Pleistocene Tillites.

LEw1s, A.N., 1924: Notes on a geological reconnaissance of Mt Anne and the Weld River Valley. Pap. Proc. $R$. Soc. Tasm. (1923): 9-42.

Qult Y, P.G., 1971: Cambrian and Ordovician dendroids and hydroids of Tasmania. J. Geol. Soc. Aust. 17: 171-190.

Raheim, A. \& Compston, W., 1977: Correlations between metamorphic events and $\mathrm{Rb}-\mathrm{Sr}$ ages in metasediments and eclogite from Western Tasmania. Lithos 10: 271-290.

SchermerhorN, L.J.G., 1974: Late Precambrian mixtites: glacial and/or non-glacial? Am. J. Sci. 274: 673-824. 
SPry, A.H., 1962: The Precambrian rocks. In Spry, A.H \& Banks, M.R. (Eds): THE GEOLOGY OF TASMANIA. J. Geol. Soc. Aust. 9: 107-126.

SPRY, A.H., 1964: Precambrian rocks of Tasmania, Part VI. The Zeehan-Corinna area. Pap. Proc, R. Soc. Tasm. 98: 23-48.

SPry, A.H. \& Zimmerman, D., 1959: The Precambrian rocks of Tasmania, Part IV. The Mt Mullens area. Pap. Proc. R. Soc. Tasm. 93: 1-9.

Turner, N.J., 1988: The Precambrian inliers and their possible relationships (abstract). In Turner, N.J. (Ed.): THE GEOLOGY AND EVOLUTION OF THE LATEST PRECAMBRIAN TO CAMBRIAN ROCKS IN THE WESTERN TASMANIAN TERRANE. Abstracts volume. Geol. Soc. Aust. (Tasm. Div.): 6-8.

Turner, N.J., 1989a: Precambrian. In Burrett, C.F. \& Martin, E, (Eds): GEOLOGY AND MINERAL RESOURCES OF TASMANIA. Geol. Soc. Aust. Spec. Publ. 15: 5-46.
Turner, N.J., 1989b: The Adamsfield District. In Burrett, C.F. \& Martin, E. (Eds): GEOLOGY AND MINERAL RESOURCES OF TASMANIA. GeOl. SOC. Aust. Spec. Publ. 15: 168-174.

Turner, N.J., Calver, C.R., McClenaghan, M.D., McClenaghan, J., Brown, A.V. \& Lennox, P.G., 1985: Pedder. Geol. Atlas 1:50000 ser. Sheet $8112 \mathrm{~S}$. Tasm. Dep. Mines.

Williams, E., 1976: Explanatory notes for the 1:500000 structural map of pre-Carboniferous rocks of Tasmania: Tasman Fold Belt System in Tasmania. Tasm. Dep. Mines.

Williams, G.E., 1975: Late Precambrian glacial climate and the Earth's obliquity. Geol. Mag. 112: 441-465. WILSON, J.L., 1975: CARBONATE FACIES IN GEOLOGIC HISTORY. Springer-Verlag, New York.

(accepted 10 February 1989) 